\title{
Marshall Space Flight Center Test Capabilities
}

\author{
Jeffrey T. Hamilton* \\ Marshall Space Flight Center, AL 35812
}

\begin{abstract}
The Test Laboratory at NASA's Marshall Space Flight Center has over 50 facilities across $400+$ acres inside a secure, fenced facility. The entire Center is located inside the boundaries of Redstone Arsenal, a 40,000 acre military reservation. About 150 Government and 250 contractor personnel operate facilities capable of all types of propulsion and structural testing, from small components to engine systems and structural strength, structural dynamic and environmental testing. We have tremendous engineering expertise in research, evaluation, analysis, design and development, and test of space transportation systems, subsystems, and components.
\end{abstract}

\section{Nomenclature}

BTU $=$ British Thermal Unit, measure of heat

$\mathrm{CH}_{4}=$ methane

ET $\quad=$ Space Shuttle External Tank

$g=$ acceleration of gravity, $32 \mathrm{ft} / \mathrm{s}^{2}$

$\mathrm{GH}_{2} \quad=$ gaseous hydrogen

$\mathrm{GHe} \quad=$ gaseous helium

$\mathrm{GN}_{2}=$ gaseous nitrogen

GOX = gaseous oxygen

gpm = gallons/minute, measure of volume flow rate

$\mathrm{lbf} \quad=$ pounds force, measure of force

$\mathrm{lbm} \quad=$ pounds mass

$\mathrm{lb} / \mathrm{s}=$ pounds $/ \mathrm{s}$, measure of mass flow rate

$\mathrm{LCH}_{4}=$ liquid methane

$\mathrm{LH}_{2} \quad=$ liquid hydrogen

LOX $=$ liquid oxygen

$P_{0} \quad=$ inlet pressure

Ppm $\quad=$ parts per million, measure of concentration

psia $=\mathrm{lb} / \mathrm{in}^{2}$ absolute

psig $=\mathrm{lb} / \mathrm{in}^{2}$ gage, pressure referenced to atmosphere

RP-1 = Rocket Propellant 1, refined kerosene

$\mathrm{rpm} \quad=$ revolutions per minute

sps $\quad=$ samples per second

SRS $\quad=$ Shock Response Spectrum, impulse response, measured in $g$ 's

$T_{0} \quad=$ inlet temperature

TPS $\quad=$ Thermal Protection System

$\mathrm{W} \quad=$ watts, measure of energy

\section{Introduction}

$\mathrm{T}$ HE Test Laboratory at NASA's Marshall Space Flight Center (MSFC) has existed as long as the Center; in fact, the oldest facilities were built by the U.S. Army Ballistic Missile Agency and were in existence before NASA was created. Marshall's test capability has been and remains a critical national asset. While many fascinating papers could be written about the history of these facilities, this paper focuses on the existing capabilities relevant to the current NASA mission.

*Technical Assistant, Test Laboratory, ET01, MSFC, AL 35812; AIAA Member 


\section{Major Facilities and Capabilities}

The test facilities at Marshall Space Flight Center are physically located in four areas, known as the East, West, and North Test Areas, and the Structural and Environmental Test Area. For the purposes of this paper they are classified by type of facility and test supported, rather than geographically. There are four major classes of facilities: Propulsion test facilities; Structural test facilities; Environmental test facilities; and Wind Tunnel facilities.

\section{A. Propulsion test facilities}

The propulsion test facilities at MSFC are used for testing of sub-scale injectors, injector elements, thrusters, gas generators, turbopumps, igniters, oxygen and hydrogen cold flow components, solid and hybrid motor propellants and materials, hot gas material characterization, and engine systems using liquid hydrogen, methane, and kerosene. The remainder of this paper details these facilities, their salient characteristics, and recent test programs.

The Advanced Fuels Facility is a multi-propellant test bed used for comparison testing of exotic hydrocarbon fuels with a baseline fuel, testing of subscale combustion devices, and new technologies such as the laser ignition of RP-1. Capabilities include $\mathrm{GN}_{2}, \mathrm{GH}_{2}$, GHe, RP-1, Missile Grade Air, a Thrust Measurement system, and laser ignition and diagnostics systems. The Advanced Fuels skid can accommodate small combustion devices about $1-\mathrm{ft}$ by $1-\mathrm{ft}$ by $2-\mathrm{ft}$ and up to 1,000 pounds thrust on the thrust table. Devices can be tested using GOX, $\mathrm{GH}_{2}, \mathrm{RP}-1$, and other hydrocarbon fuels with conventional or laser ignition devices. For fuels comparison

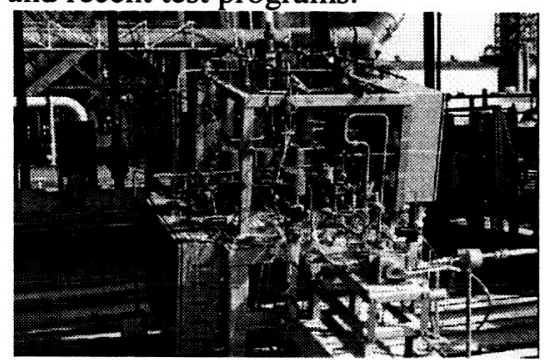
testing, two nine-gallon fuel tanks rated at $750 \mathrm{psig}$ are used. The fuel flow rate is $0.5 \mathrm{lb} / \mathrm{s}$. Combustion is initiated using RP-1, and then the tanks are switched while the engine is firing for real-time performance comparison of an alternative fuel with RP-1.

The Solid Propulsion Test Facility has two positions, horizontal and vertical, for testing 48-inch diameter solid rocket motors to 100,000 pounds thrust vertically inverted (nozzle up) and 24-inch diameter solid rocket motors to 172,000 pounds thrust horizontally. This facility provides a simulated Shuttle solid rocket motor combustion environment to evaluate

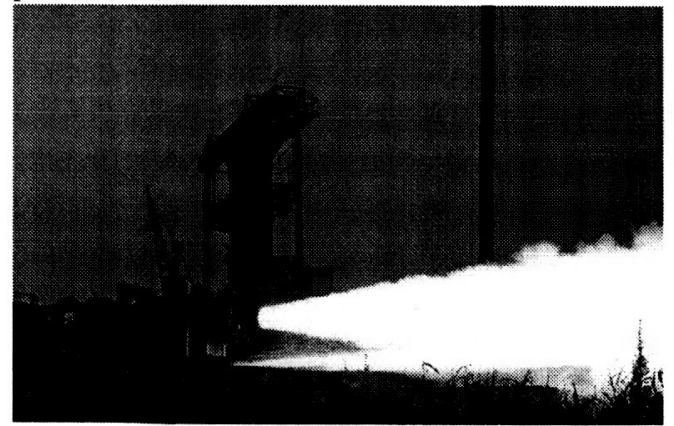
performance data, solid rocket motor internal case instrumentation, nonasbestos insulation materials, nozzle designs, materials, and new inspection techniques such as RealTime Radiography. The Solid Propulsion Test Facility is currently being used to support Space Shuttle Reusable Solid Rocket Motor tests using the 24-inch and 48-inch solid rocket motors.

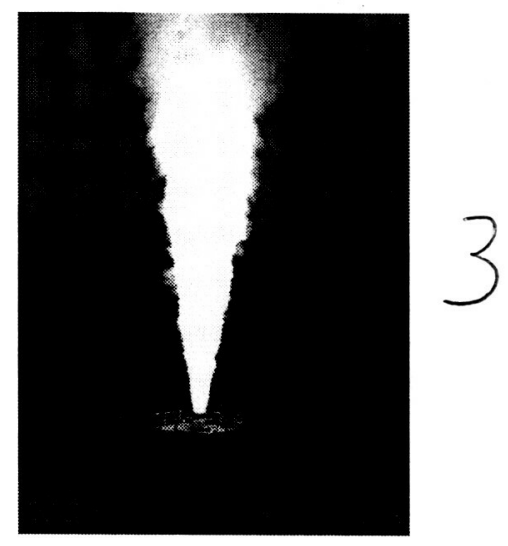

\begin{tabular}{|l|l|}
\hline \multicolumn{2}{|c|}{ Table 1. Solid Propulsion Test Facility Capabilities } \\
\hline $\mathrm{GN}_{2}$ & 1-inch line, 4,200 psig \\
\hline Missile-Grade Air & 1 -inch line, 3,500 psig \\
\hline Industrial water & $150 \mathrm{psig}$ \\
\hline Low speed digital data & $200 \mathrm{sps}$ \\
\hline High speed digital data & $250,000 \mathrm{sps}$ \\
\hline Real-time video with sound & 30 frames per second \\
\hline High speed film camera & 400 frames per second \\
\hline High speed digital video & 1,000 frames per second for 52 seconds \\
\hline
\end{tabular}

The Test Cells are used for up to 5000 pounds thrust solid and hybrid test articles. The test cells are a group of 11 adjacent reinforced-concrete, blast-resistant positions measuring 15 feet wide by 15 feet deep by 10 feet high that

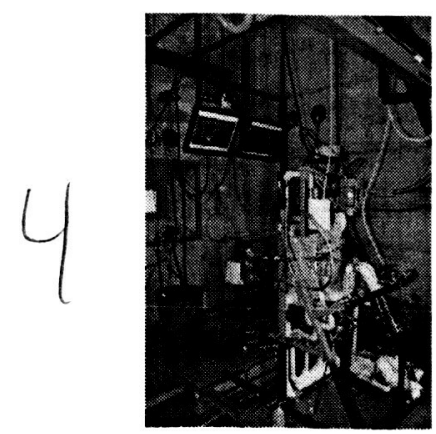
have the pressurizing gases and propellants for testing scale model combustion devices and rocket engines. The cells are less expensive to run than other facilities due to the small amounts of propellant required to perform tests. Active positions are now

\section{2}

American Institute of Aeronautics and Astronauti

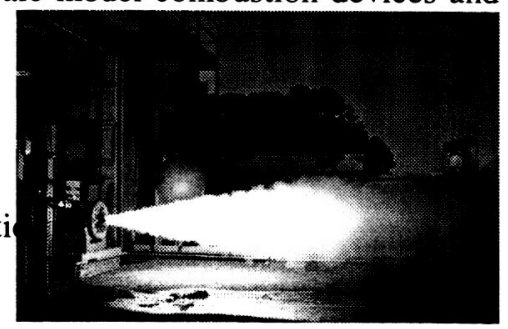


involved in small scale Shuttle solid motor and External Tank foam environment generation for materials and instrumentation evaluation and also support real-time radiography of solid rocket motor composite nozzles.

\begin{tabular}{|l|l|}
\hline \multicolumn{2}{|c|}{ Table 2. Test Cells Facility Capabilities } \\
\hline $\mathrm{GN}_{2}$ & 1-inch line, $4,200 \mathrm{psig}$ \\
\hline Missile-Grade Air & 1-inch line, $3,500 \mathrm{psig}$ \\
\hline Industrial water & $150 \mathrm{psig}$ \\
\hline $\mathrm{GOX}$ & Tube trailer, 236 $\mathrm{ft}^{3}$ at $2,400 \mathrm{psig}$ \\
\hline $\mathrm{GHe}$ & Tube trailer, 238 $\mathrm{ft}^{3}$ at $4,500 \mathrm{psig}$ \\
\hline Low speed digital data & $200 \mathrm{sps}$ \\
\hline High speed digital data & $250,000 \mathrm{sps}$ \\
\hline Real-time video with sound & 30 frames per second \\
\hline High speed film camera & 400 frames per second \\
\hline High speed digital video & 1,000 frames per second for 52 seconds \\
\hline
\end{tabular}

Test Facility position facility subscale engine small flow rate facility's testing subscale by an in-house development Combustor Test Article Staged Combustion Injector Technology test.
115 is a multipurpose, multicapable of testing small or systems and medium pressure, combustion devices. The compact size makes it ideal for components. It was recently used MSFC combustion component program known as the Modular

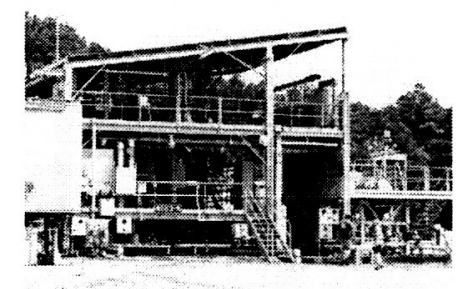

\begin{tabular}{|c|c|}
\hline $\mathrm{LH}_{2} / \mathrm{CH}_{4}$ & $\begin{array}{l}2,200 \text { gallons at } 1,500 \mathrm{psig} \\
500 \text { gallons at } 3,000 \mathrm{psig}\end{array}$ \\
\hline $\mathrm{CH}_{4} / \mathrm{RP}-1$ & 20 gallons at 3,000 psig \\
\hline $\mathrm{LH}_{2}$ flow & $1.5 \mathrm{lb} / \mathrm{s}$ \\
\hline RP-1 flow & $7 \mathrm{lb} / \mathrm{s}$ \\
\hline $\mathrm{LCH}_{4}$ flow & $4.5 \mathrm{lb} / \mathrm{s}$ \\
\hline LOX & $\begin{array}{l}500 \text { gallons at } 3,000 \mathrm{psig} \text {, future } 25,000 \\
\text { gallons }\end{array}$ \\
\hline LOX flow & $8 \mathrm{lb} / \mathrm{s}$ \\
\hline GOX & Tube trailer, $236 \mathrm{ft}^{3}$ at $2,400 \mathrm{psig}$ \\
\hline GOX/LOX Heat Exchanger & $3 \mathrm{lb} / \mathrm{s}$ \\
\hline $\mathrm{GH}_{2}$ & $\begin{array}{l}\text { Tube trailer, } 157 \mathrm{ft}^{3} \text { at } 3,800 \mathrm{psig} \text {, future } \\
940 \mathrm{ft}^{3} \text { at } 4,100 \mathrm{psig} \text {, capable of } 5 \mathrm{lb} / \mathrm{s}\end{array}$ \\
\hline $\mathrm{GHe}$ & Tube trailer, $238 \mathrm{ft}^{3}$ at $4,500 \mathrm{psig}$ \\
\hline $\mathrm{GN}_{2}$ & 3-inch line, $4,200 \mathrm{psig}$ \\
\hline Demineralized Water & 500 gallons at $3,000 \mathrm{psig}, 15 \mathrm{lb} / \mathrm{s}$ \\
\hline Missile-Grade Air & 1-inch line, $3,500 \mathrm{psig}$ \\
\hline Industrial water & 150 psig \\
\hline Hydraulics & $10 \mathrm{gpm}$ at $3,000 \mathrm{psig}$ \\
\hline Low speed digital data & $200 \mathrm{sps}$ \\
\hline High speed digital data & $250,000 \mathrm{sps}$ \\
\hline Real-time video with sound & 30 frames per second \\
\hline High speed film camera & 400 frames per second \\
\hline High speed digital video & 1,000 frames per second for 52 seconds \\
\hline
\end{tabular}

Test Facility 116 is ideal for testing high-pressure engine system components, turbo pumps, valves, cryogenic propellant system components, and combustion devices to 150,000 pounds thrust. This multi-position stand can run multiple tests simultaneously and also can be used for acoustic environmental simulation tests. There are six 
positions at this facility: Turbine Blade Position, Acoustic Model Position (30,000-lb thrust), Turbopump Position, Pre-burner Position (50,000-lb thrust), High-flow Water Position, and the 60,000-lb Thrust Position (upgraded 40K Position). Most recently, Test Facility 116 was used for testing the 50,000 pound thrust RS-88 LOX-Ethanol engine for the Orbital Space Plane Pad Abort Demonstrator test.

\begin{tabular}{|c|c|}
\hline $\mathrm{LH}_{2}$ & $\begin{array}{l}2,200 \text { gallons at } 6,000 \mathrm{psig} \\
2,000 \text { gallons at } 8,500 \mathrm{psig}\end{array}$ \\
\hline $\mathrm{LH}_{2}$ flow & $\begin{array}{l}\text { 60k position: } 25 \mathrm{lb} / \mathrm{s} \\
\text { Pre-burner position: } 90 \mathrm{lb} / \mathrm{s} \\
\text { Turbine Blade position: } 3 \mathrm{lb} / \mathrm{s}\end{array}$ \\
\hline RP-1/High Pressure Water & $\begin{array}{l}3,000 \text { gallons at } 4,750 \mathrm{psig} \\
3,000 \text { gallons at } 2,700 \mathrm{psig} \\
\end{array}$ \\
\hline RP-1/High Pressure Water flow & $\begin{array}{l}\text { 60k position: } 100 \mathrm{lb} / \mathrm{s} \\
\text { Turbopump position: } 60 \mathrm{lb} / \mathrm{s} \\
\text { High-flow position: } 7,500 \mathrm{gpm} \text { for } 11.8 \mathrm{~s}\end{array}$ \\
\hline LOX & 3,000 gallons at $5,250 \mathrm{psig}$ \\
\hline LOX Storage & 28,000 gallons and 14,000 gallons \\
\hline LOX flow & $\begin{array}{l}\text { 60k position: } 160 \mathrm{lb} / \mathrm{s} \\
\text { Pre-burner position: } 160 \mathrm{lb} / \mathrm{s} \\
\text { Acoustic Model position: } 20 \mathrm{lb} / \mathrm{s} \\
\text { Turbine Blade position: } 10 \mathrm{lb} / \mathrm{s} \\
\text { Turbopump position: } 160 \mathrm{lb} / \mathrm{s} \\
\end{array}$ \\
\hline $\mathrm{GH}_{2}$ & $\begin{array}{l}600 \mathrm{ft}^{3} \text { at } 10,000 \mathrm{psig} \\
1,250 \mathrm{ft}^{3} \text { at } 15,000 \mathrm{psig} \\
1.5 \text {-inch line at } 4,400 \text { psig } \\
\end{array}$ \\
\hline $\mathrm{GH}_{2}$ flow & $\begin{array}{l}\text { Pre-burner position, } 10 \mathrm{lb} / \mathrm{s} \\
\text { Acoustic Model position, } 2 \mathrm{lb} / \mathrm{s}\end{array}$ \\
\hline $\mathrm{GHe}$ & 1.5 -inch line at $4,200 \mathrm{psig}$ \\
\hline $\mathrm{GN}_{2}$ & $\begin{array}{l}1,250 \mathrm{ft}^{3} \text { at } 10,000 \mathrm{psig} \\
700 \mathrm{ft}^{3} \text { at } 8,000 \mathrm{psig} \\
3 \text {-inch line, } 4,200 \mathrm{psig} \\
\end{array}$ \\
\hline Missile-Grade Air & 1.5-inch line, $3,500 \mathrm{psig}$ \\
\hline Industrial water & 150 psig \\
\hline Hydraulics & 50 gpm at 3,000 psig \\
\hline Low speed digital data & 200 sps \\
\hline High speed digital data & $250,000 \mathrm{sps}$ \\
\hline Real-time video with sound & 30 frames per second \\
\hline High speed film camera & 400 frames per second \\
\hline High speed digital video & 1,000 frames per second for 52 seconds \\
\hline
\end{tabular}

Test Facility $\mathbf{5 0 0}$ is a six position stand designed for hazardous testing of $\mathrm{LH}_{2}, \mathrm{LOX}$, solid, and hybrid propulsion components and subsystems including combustion devices, propellant pumps, bearings, tanks and valves. The bearing drives are a 500 horsepower diesel engine with a variable-speed transmission to 40,000 RPM for the LOX position and a pressurizing gas $\left(\mathrm{GN}_{2}\right)$ with an electro-hydraulic valve controller for the $\mathrm{LH}_{2}$ position. The six positions at this facility are:

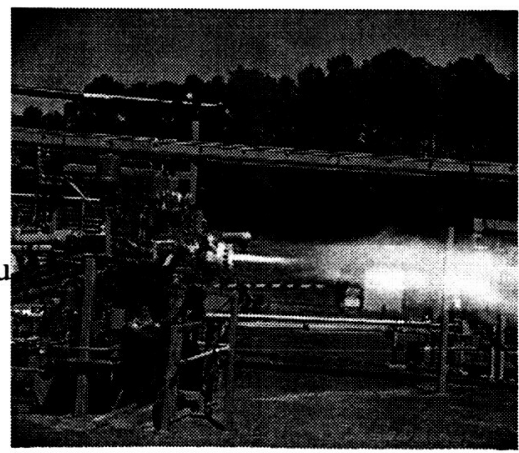


$\mathrm{LH}_{2} /$ LOX Component Test Position A and Test Position B, the 24-inch Solid/LOX Hybrid Motor Position, the LOX Bearing Test Position, the $\mathrm{LH}_{2}$ Bearing Test Position, and the Propellant Tank Position. Test Facility 500 is presently being used by KT Engineering of Huntsville, Alabama to test their modular thruster design.

\begin{tabular}{|l|l|}
\hline \multicolumn{2}{|c|}{ Table 5. Test Facility 500 Capabilities } \\
\hline & $\begin{array}{l}5,000 \text { gallons at } 2,000 \text { psig } \\
36,000 \text { gallons at } 100 \text { psig (elevated) } \\
100,000 \text { gallons at } 75 \text { psig (inactive) }\end{array}$ \\
\hline $\mathrm{LH}_{2}$ flow & $11 \mathrm{lb} / \mathrm{s}$ \\
\hline $\mathrm{LN}_{2}$ & 3,000 gallons at 1,000 psig \\
\hline $\mathrm{LN}_{2}$ Flow & $35 \mathrm{lb} / \mathrm{s}$ \\
\hline LOX & 3,000 gallons at 2,000 psig \\
& 23,000 gallons at 80 psig (elevated) \\
\hline LOX Storage & 28,000 gallons at 50 psig \\
\hline LOX flow & $70 \mathrm{lb} / \mathrm{s}$ \\
\hline GH & 3 -inch line, at 4,200 psig \\
\hline GHe & 3 -inch line, at 4,200 psig \\
\hline GN 2 & 3 -inch line, 4,200 psig \\
\hline Missile-Grade Air & 1.5 -inch line, 3,500 psig \\
\hline Industrial water & 150 psig \\
\hline Hydraulics & A: 5 gpm at 3,000 psig \\
& B: 11 gpm at 3,000 psig \\
\hline Low speed digital data & 200 sps \\
\hline High speed digital data & 250,000 sps \\
\hline Real-time video with sound & 30 frames per second \\
\hline High speed film camera & 400 frames per second \\
\hline High speed digital video & 1,000 frames per second for 52 seconds \\
\hline
\end{tabular}

The Advanced Engine Test Facility is a 1,000,000 pound thrust LOX/RP-1 and $\mathrm{LOX} / \mathrm{LH}_{2}$ test facility. This two-position, tri-propellant facility is capable of evaluating and characterizing full-up engine and vehicle stage systems in the vertical configuration. Position 1 is configured as a $\mathrm{LOX}_{\mathrm{LH}}$ position with the piping interface designed to mate to a Space Shuttle Main Engine with a thrust structure rated for 375,000 pounds. Thrust measurement is available. Position 2 is configured as a LOX/RP-1 position with the piping interface designed to mate to the Atlas propulsion module for testing the Russian RD180 engine with a thrust structure rated for 900,000 pounds. Thrust measurement is available in the vertical direction only in Position 2. The Advanced Engine Test Facility has been used to test a single Space Shuttle Main Engine 66 times. It was also used to hot-fire the Lockheed Martin Atlas RD-180 LOX/RP-1 engine four times. It is presently is a stand-by mode with purges active.

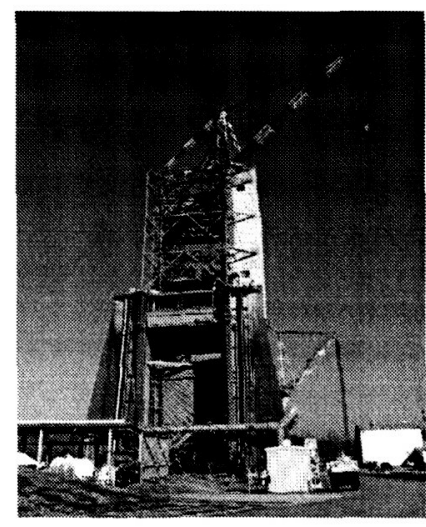

\begin{tabular}{|c|c|}
\hline $\mathrm{LH}_{2}$ & $\begin{array}{l}\text { Position } 1: 75,000 \text { gallons at } 50 \text { psig } \\
450,000 \text { gallons at } 100 \text { psig storage }\end{array}$ \\
\hline $\mathrm{LH}_{2}$ flow & $11 \mathrm{lb} / \mathrm{s}$ \\
\hline RP-1 & $\begin{array}{l}6,000 \text { gallons at } 130 \mathrm{psig} \\
14,000 \text { gallons at } 150 \mathrm{psig} \\
20,000 \text { gallons storage }\end{array}$ \\
\hline LOX & $\begin{array}{l}\text { Position 1: } 23,000 \text { gallons at } 150 \text { psig } \\
\text { Position 2: } 12,000 \text { gallons at } 130 \text { psig }\end{array}$ \\
\hline \begin{tabular}{|l} 
LOX Storage \\
\end{tabular} & 78,000 gallons at $100 \mathrm{psig}$ \\
\hline LOX flow & $\begin{array}{l}1,288 \mathrm{lb} / \mathrm{s} \text {, limited only by } 25 \mathrm{ft} / \mathrm{s} \mathrm{LOX} \\
\text { velocity constraint }\end{array}$ \\
\hline
\end{tabular}




\begin{tabular}{|c|c|}
\hline $\mathrm{GH}_{2}$ & $11,400 \mathrm{ft}^{3}$ at $3,100 \mathrm{psig}$ \\
\hline $\mathrm{GHe}$ & $\begin{array}{l}2,500 \mathrm{ft}^{3} \text { at } 4,200 \mathrm{psig} \\
90 \mathrm{ft}^{3} \text { at } 10,000 \text { psig }\end{array}$ \\
\hline $\mathrm{GN}_{2}$ & $\begin{array}{l}\text { 6.0-inch line, } 4,200 \text { psig } \\
3,750 \mathrm{ft}^{3} \text { at } 4,200 \text { psig } \\
\end{array}$ \\
\hline Missile-Grade Air & Two 1.5 -inch lines, 3,500 psig \\
\hline Industrial water & $\begin{array}{l}\text { Storage of } 7,000,000 \text { gallons for firex and } \\
\text { deflector cooling }\end{array}$ \\
\hline Deflector cooling & $200,000 \mathrm{gpm}$ at $150 \mathrm{psig}$ \\
\hline Firex & $110,000 \mathrm{gpm}$ at $150 \mathrm{psig}$ \\
\hline Hydraulics & Two $15 \mathrm{gpm}$ at $5,000 \mathrm{psig}$ \\
\hline Low speed digital data & $200 \mathrm{sps}$ \\
\hline High speed digital data & $250,000 \mathrm{sps}$ \\
\hline Real-time video with sound & 30 frames per second \\
\hline High speed film camera & 400 frames per second \\
\hline High speed digital video & 1,000 frames per second for 52 seconds \\
\hline
\end{tabular}

\section{B. Structural Facilities}

Structural Strength Test provides load environments to simulate launch, on-orbit, and landing conditions for development, qualification, acceptance and research testing of space flight hardware. It maintains the capability for instrumentation (strain gages, deflections, loads, pressures, temperature, and humidity), data acquisition $(4,600$ channels), pressure control (ambient and cryogenic), flow control (pneumatic, ambient liquids, cryogenic $\mathrm{LN}_{2}, \mathrm{LHe}$, and $\mathrm{LH}_{2}$ ), temperature control and mechanical load control.

Hazardous Structural Strength Test facility (Building 4572) accommodates full scale test articles

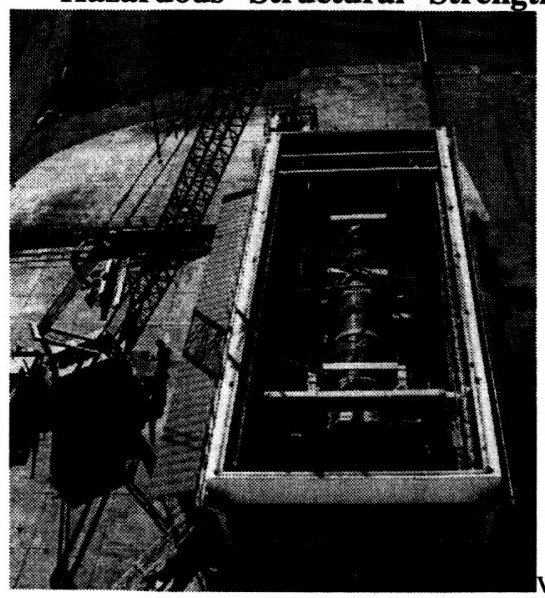

with high loads and pressures. 4,600 instrumentation channels are available, along with a large inventory of load cells, pressure sensors, and displacement sensors.

Table 7. Hazardous Structural Test Facility, Building 4572

\begin{tabular}{|l|l|}
\hline \multicolumn{2}{|c|}{ Table 7. Hazardous Structural Test Facility, Building 4572 } \\
\hline Test Bay dimensions & $40-\mathrm{ft} \times$ 94- $\mathrm{ft}$ x 48-ft \\
\hline Floor & Reinforced concrete 5-ft thick \\
\hline Roof & $\begin{array}{l}\text { Removable for test article installation and } \\
\text { removal }\end{array}$ \\
\hline End walls & $\begin{array}{l}\text { 12-ft thick concrete. Capable of reacting } \\
\text { loads of 2,500,000 lbf }\end{array}$ \\
\hline Cranes & $\begin{array}{l}\text { Bridge crane with two independent } \\
\text { trolleys rated at 5,000 lb each }\end{array}$ \\
\hline
\end{tabular}

Cryogenic Structural Test Facility (Building 4699) can be used to evaluate the structural integrity of tanks and other propulsion components under a variety of conditions using compression, sheer, and tension loads, while filled 
with gases or cryogens. Inside the facility is a 30 - $\mathrm{ft}$ by 30 - $\mathrm{ft}$ concrete test pad measuring $2 \mathrm{ft}$ thick. The Cryogenic Structural Test Facility most recently was used for the Northrop-Grumman composite hydrogen tank tests.

Table 8. Cryogenic Structural Test Facility Capabilities

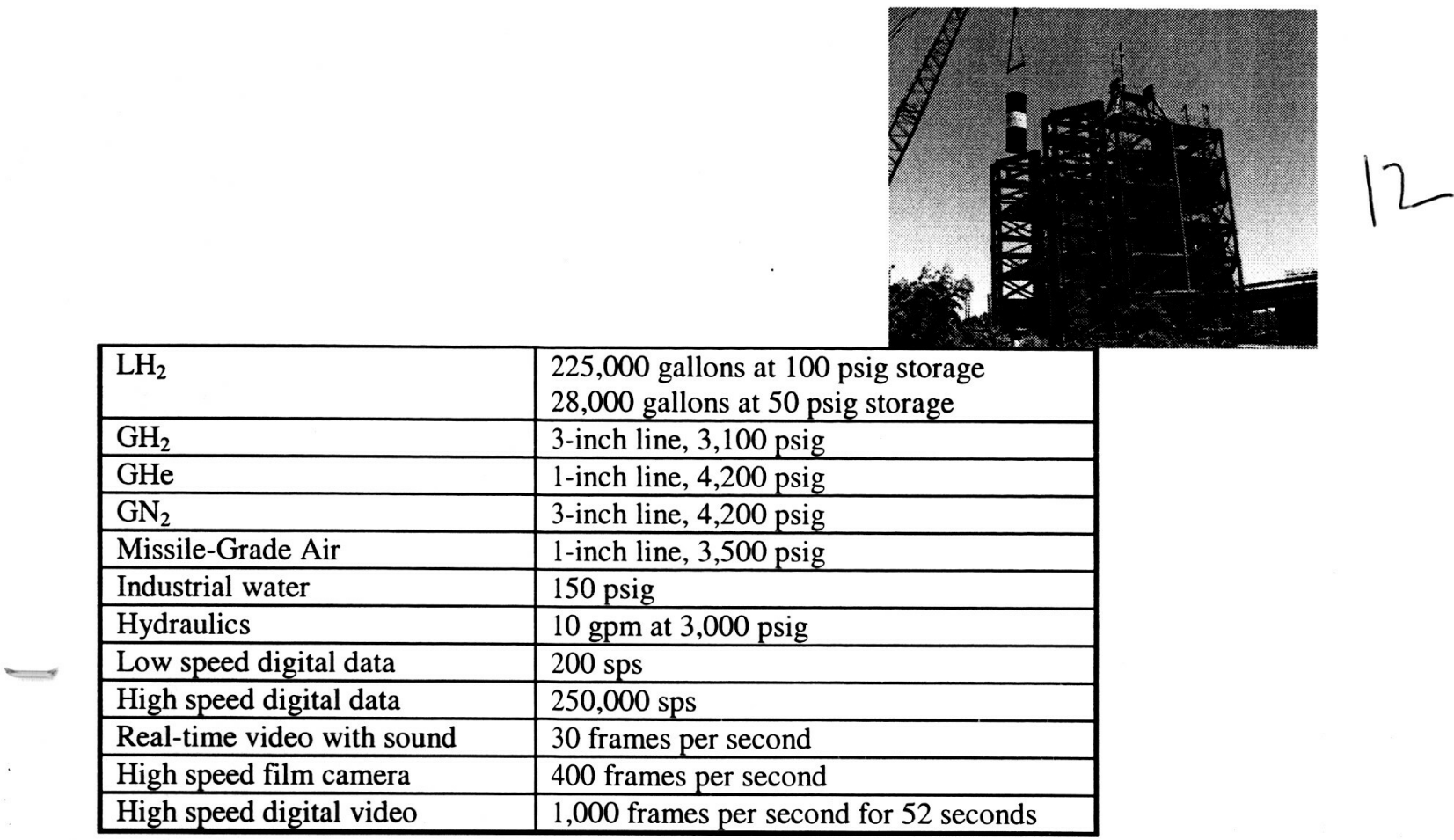

Structural Strength Test High Bay Facility consists of two adjacent high-bay areas inside Building 4619. They feature 4,600 channels of data acquisition; support for four large scale tests in parallel; engineering data computed in background during acquisition; test-generated 3D Finite Element Model displays; and stress analyst stations to support real time monitoring and plotting. The following two tables summarize the

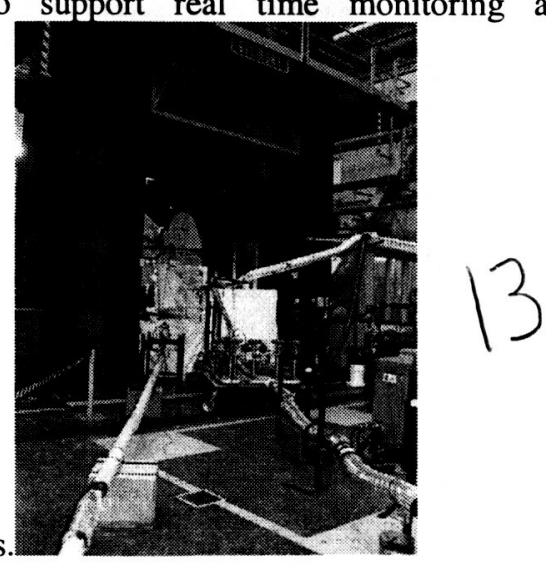

capabilities

Table 9. Structural Strength Test East High-Bay Facility

\begin{tabular}{|l|l|}
\hline Access door dimensions & $40-\mathrm{ft} \times 40-\mathrm{ft}$ \\
\hline Reaction floor dimensions & $64-\mathrm{ft} \times 154-\mathrm{ft}, 11-\mathrm{ft}$ thick \\
\hline Tie-downs & $\begin{array}{l}\text { Load plates (each containing four tie- } \\
\text { downs) symmetrically affixed on 10-ft } \\
\text { centers. Each plate capable of } 340 \mathrm{klbf} \text { in } \\
\text { tension and } 44 \mathrm{klbf} \text { in shear. }\end{array}$ \\
\hline
\end{tabular}




\begin{tabular}{|l|l|}
\hline Cranes & $\begin{array}{l}\text { Two 25-ton bridge cranes each with one } \\
\text { 25-ton trolley. Each trolley has } \\
\text { independent 20-ton and 5-ton hooks; } 80-\mathrm{ft} \\
\text { hook height }\end{array}$ \\
\hline Test article height & Up to 75-ft \\
\hline Universal Test Machines & $\begin{array}{l}\text { Tensile and compressive loads 120 klbf, } \\
\text { 260 klbf, 2 Mlbf and 3 Mlbf }\end{array}$ \\
\hline Modular test frames & $\begin{array}{l}\text { Three frames accommodate loads of 10, } \\
50, \text { and } 100 \text { klbf. Frame volumes: 6-ft } \\
\text { cube, 10-ft cube, and 20-ft cube }\end{array}$ \\
\hline Load application & $\begin{array}{l}\text { Hydraulic actuators (1-1/8-inch to 33-inch } \\
\text { bore) }\end{array}$ \\
& Closed loop servo load control: 1, 128 \\
& channel system or 2, 64 channel systems; \\
& 1,48 channel system; 2, 32 channel \\
& systems \\
& Closed loop pressurization system: \\
& Hydrostatic to 1,000 psig; pneumatic to \\
& 5,000 psig \\
\hline
\end{tabular}

\begin{tabular}{|c|c|}
\hline Access door dimensions & $57-\mathrm{ft} \times 75-\mathrm{ft}$ \\
\hline Reaction floor dimensions & $81-\mathrm{ft} \times 82-\mathrm{ft}, 10-\mathrm{ft}$ thick \\
\hline Tie-downs & $\begin{array}{l}\text { On } 18 \text {-inch centers, each capable of } 111.3 \\
\text { klbf in tension and } 19.4 \mathrm{klbf} \text { in shear. } \\
\text { Total shear reaction capability } 2.4 \mathrm{Mlbf}\end{array}$ \\
\hline Crosshead & $\begin{array}{l}\text { Positioned from } 40 \text {-ft to } 115 \text {-ft height in } \\
5.5 \text {-inch increments. Reaction capability } \\
30 \text { Mlbf. }\end{array}$ \\
\hline Cranes & $\begin{array}{l}\text { Two 30-ton bridge cranes each with two } \\
15 \text {-ton single hook trolleys. }\end{array}$ \\
\hline Test Article height & Up to $100-\mathrm{ft}$ high by $54-\mathrm{ft}$ diameter \\
\hline
\end{tabular}

Structural Dynamics Modal test provides experimentally determined frequency, damping and mode shape (eigenvalues and eigenvectors) of flight structural systems and components, DC-35,000 Hz. Provides experimental data to verify and correlate analytical finite element models of flight hardware. The fixed base facility accommodates shuttle cargo bay payloads up to $210,000 \mathrm{lbm}$ per side, fixed to bedrock. Full-field holography of

displacements $(\mathrm{DC}-35,000 \mathrm{~Hz})$ with $125-\mathrm{nm}$

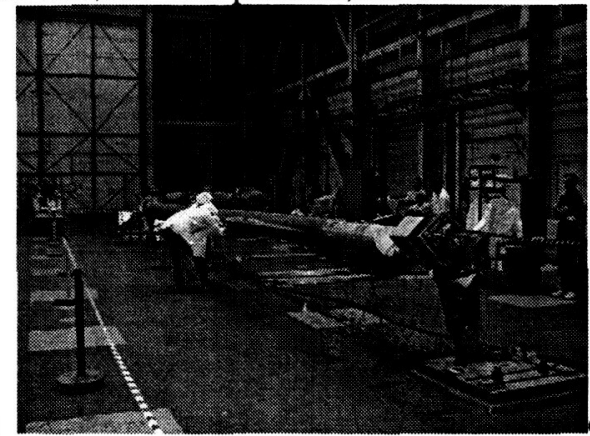<smiles>C1CCC1</smiles>
available. The component/small channel capability provides both fixed-base boundaries and free-free boundaries. The scanning laser vibrometer allows non-contact measurements to characterize the dynamics of inflatable systems. The segmented adaptive optics lab (36 segment primary mirror) has all segments actively controlled (tip \& tilt to $200 \mathrm{~Hz}$, piston to $90 \mathrm{~Hz}$ ) and features a Hartmann-Shack wave-front sensor with interferometer resolution to 632 $\mathrm{nm}$. The facility also includes a micro-gravity vibration isolation lab for vibration isolation actuator development 
and test and for micro-gravity payload/support equipment vibration and acoustic emission characterization over the International Space Station required range of $0.01-300 \mathrm{~Hz}$.

Structural Dynamics Vibration Test is used to verify design concepts subject to flight vehicle dynamic loads (launch, on-orbit, and landing) and to certify flight articles (payloads, support equipment, and components) for flight

vehicle dynamic loads. Capabilities include eight

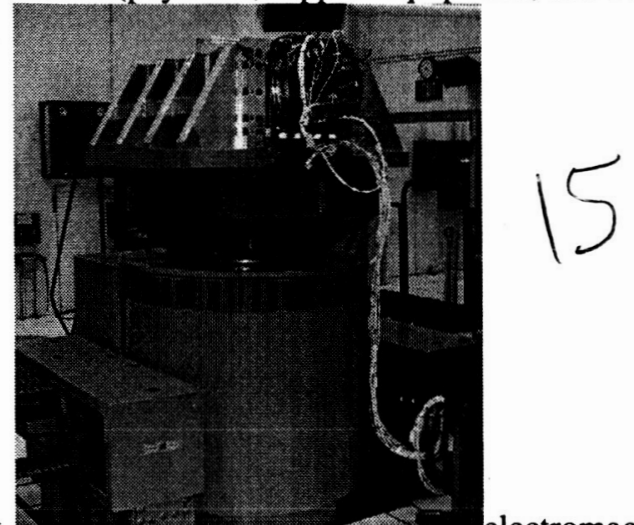

$40,000 \mathrm{lbf}$ ) that can accommodate a test article up to $5 \mathrm{ft}^{2}$. Signal conditioning and acquisition is provided by two systems with 32 channels of response and control data and two systems with 16 channels of response and control data. Modes of vibration spectra available include sine and random, sine on random and random on random, and classical shock and shock response spectrum (SRS).

Structural Dynamics Vibroacoustics test is used to verify design concepts subject to flight vehicle dynamic loads (launch, on-orbit, and landing), to certify flight articles (payloads, support equipment, and components) for flight vehicle dynamic loads, and to verify and certify flight articles (payloads, support equipment and components)

meet acoustic emission requirements. Capabilities

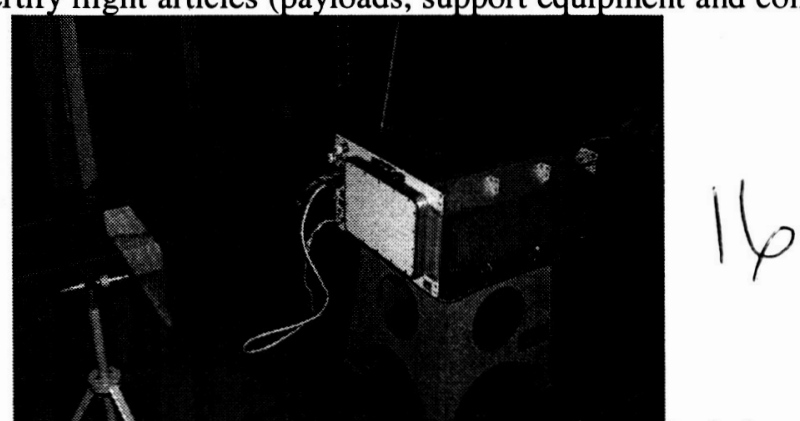

diffuse field environment to $165 \mathrm{~dB}$ and progressive waves to $170 \mathrm{~dB}$ with transmissibility ranging from reverberation to anechoic. Excitation control is provided by eight microphone channels. Acoustic excitation is available up to $200 \mathrm{~kW}$. The facility can accommodate a test article up to $500 \mathrm{ft}^{3}$ through 8 - $\mathrm{ft}$ by 8 - $\mathrm{ft}$ access doors. The anechoic chamber is quieter than NC-40 requirements and allows sound pressure and sound power measurements.

Structural Dynamics Pyrotechnic Shock test is used to verify design concepts subject to flight vehicle dynamic loads (launch, on-orbit, and landing), and to certify flight articles (payloads, support equipment, and

components) for flight vehicle dynamic loads. Capabilities

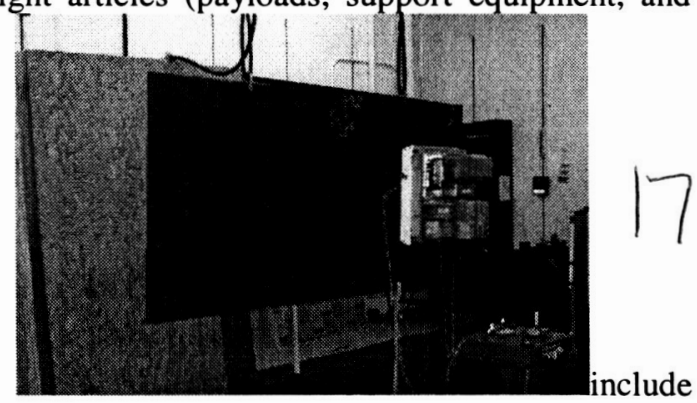
pyrotechnic excitation sources that generate up to 30,000 g's SRS and 20,000 Hz. Instrumentation includes accelerometers capable of up to 50,000 g's. Test articles up to $500 \mathrm{ft}^{3}$ can be accommodated. Signal conditioning and data acquisition is provided by a 16-channel system. Time and Shock Response Spectrum analysis is provided. 


\section{Environmental Test Facilities}

The Environmental Test Facility in Building 4619 provides space thermal vacuum simulation environments for development, qualification, acceptance and research testing of space flight hardware. The facility is located in the West High Bay, a $70-\mathrm{ft}$ by $150-\mathrm{ft}$ space with a $24-\mathrm{ft}$ x $35-\mathrm{ft}$ access door and two $20-\mathrm{ft}$ x $30-\mathrm{ft}$ access doors. The $70-\mathrm{ft}$ by 150 -ft concrete floor is ten feet thick. The facility features two overhead bridge cranes with dual independent trolley hooks, one with 20,000 pound capacity and one with 6,000 pound capacity. Hook height is 80 -ft. The Environmental Test Facility provides the following test capabilities: thermal vacuum; vacuum bakeout; optical cleanliness vacuum bakeout; life-cycle testing; launch depressurization simulation; and altitude/thermal/humidity.

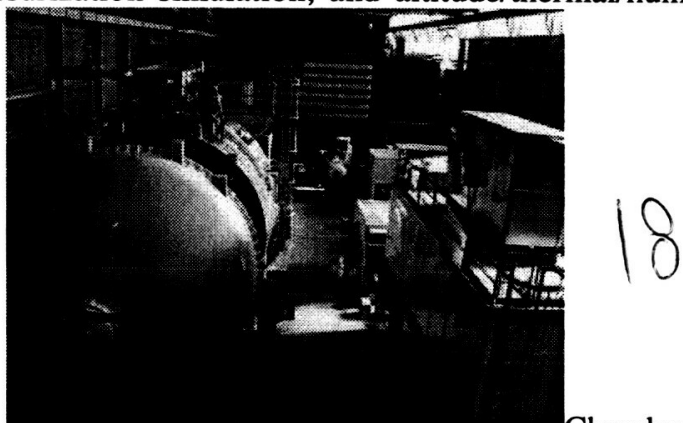

testing. Test Facilities include 14 Thermal Vacuum Test Chambers; 5 Thermal Humidity Test Chambers; 1 Thermal Altitude Chamber; 1 Class 10K Clean Room; and 1 Class 100K Clean Room. The facility performs $270-340$ Tests and Test Series per year. The following chart shows the various chambers and their salient characteristics.

\begin{tabular}{|c|c|c|c|c|c|}
\hline CHAMBER & PRIMARY USE & $\begin{array}{l}\text { VACUUM } \\
\text { PRESSURES * }\end{array}$ & TEMPERATURES & $\begin{array}{l}\text { THERMAL } \\
\text { CONDITIONING }\end{array}$ & DIMENSIONS \\
\hline v1 & Optical Cleanliness & $5 \times 10^{-7}$ torr & Ambient to $180^{\circ} \mathrm{C}$ & Infrared Lamps & $4 \mathrm{ft}$ dia. $\times 7 \mathrm{ft}$ \\
\hline V2 & Optical Cleanliness & $5 \times 10^{-8}$ torr & Ambient to $180^{\circ} \mathrm{C}$ & Infrared Lamps & $4 \mathrm{ft}$ dia. $\times 10 \mathrm{ft}$ \\
\hline v3 & Life Cycle & $5 \times 10^{-8}$ torr & -100 to $100^{\circ} \mathrm{C}$ & Infrared Lamps, $\mathrm{LN}_{2}$ & $4 \mathrm{ft} \mathrm{dia.} \times 10 \mathrm{ft}$ \\
\hline V4 \& V8 & Vacuum Bakeout & $1 \times 10^{-6}$ torr & Ambient to $175^{\circ} \mathrm{C}$ & Infrared Lamps & $2 \mathrm{ft} \mathrm{dia.} \times 2.5 \mathrm{ft}$ \\
\hline v5 & Vacuum Bakeout & $1 \times 10^{-6}$ torr & -170 to $150^{\circ} \mathrm{C}$ & Infrared Lamps, $\mathrm{LN}_{2}$ & $3 \mathrm{ft}$ dia. $\times 4 \mathrm{ft}$ \\
\hline V6 & Vacuum Bakeout & $1 \times 10^{-7}$ torr & -170 to $150^{\circ} \mathrm{C}$ & Infrared Lamps, $\mathrm{LN}_{2}$ & $3 \mathrm{ft}$ dia. $\times 4$ \\
\hline BUNDLE & Thermal Vacuum & $1 \times 10^{-7}$ torr & Ambient to $180^{\circ} \mathrm{C}$ & Infrared Lamps & $3 \mathrm{ft}$ dia. $\times 5 \mathrm{v}$ \\
\hline v7 & Optical Cleanliness & $5 \times 10^{-7}$ torr & -170 to $150^{\circ} \mathrm{C}$ & Infrared Lamps, $\mathrm{LN}_{2}$ & $8 \mathrm{ft}$ dia. $\times 10 \mathrm{ft}$ \\
\hline v9 & Launch Depress & $1 \times 10^{-6}$ torr & Ambient & Infrared Lamps, $\mathrm{LN}_{2}$ & $4 \mathrm{ft}$ dia. $\times 7 \mathrm{ft}$ \\
\hline V10 & Life Cycle & $5 \times 10^{-8}$ torr & Ambient to $100^{\circ} \mathrm{C}$ & Infrared Lamps, $\mathrm{LN}_{2}$ & $1.5 \mathrm{ft}$ dia. $\times 1.5 \mathrm{ft}$ \\
\hline V11 & Thermal Vacuum & $1 \times 10^{-6}$ torr & Ambient to $180^{\circ} \mathrm{C}$ & Infrared Lamps, $\mathrm{LN}_{2}$ & $8 \mathrm{ft} \mathrm{dia.} \times 10 \mathrm{ft}$ \\
\hline V12 & Thermal Vacuum & $1 \times 10^{-6}$ torr & -100 to $100^{\circ} \mathrm{C}$ & Infrared Lamps, $\mathrm{LN}_{2}$ & $1.5 \mathrm{ft}$ dia. $\times 2 \mathrm{ft}$ \\
\hline Sunspot & Thermal Vacuum & $1 \times 10^{-6}$ torr & -170 to $200^{\circ} \mathrm{C}$ & Infrared Lamps, $\mathrm{LN}_{2}$ & $10 \mathrm{ft}$ dia. $\times 12 \mathrm{ft}$ \\
\hline $\mathrm{V} 20$ & Thermal Vacuum & $1 \times 10^{-6}$ torr & -170 to $200^{\circ} \mathrm{C}$ & Infrared Lamps, $\mathrm{LN}_{2}$ & $20 \mathrm{ft}$ dia. $\times 27 \mathrm{ft}$ \\
\hline TH-1, TH-2, TH-3 & Thermal Humidity & Ambient & -70 to $190^{\circ} \mathrm{C}$ & $\begin{array}{l}\text { Electrical Resistive, } \\
\text { Refrigeration }\end{array}$ & $4 \mathrm{ft} \times 4 \mathrm{ft} \times 4 \mathrm{ft}$ \\
\hline TH $-4 \&$ TH-8 & Thermal Humidity & Ambient & -70 to $160^{\circ} \mathrm{C}$ & $\begin{array}{l}\text { Electrical Resistive, } \\
\text { Refrigeration }\end{array}$ & $4 \mathrm{ft} \times 4 \mathrm{ft} \times 4 \mathrm{ft}$ \\
\hline TA-1 & Thermal Altitude & Ambient to $100,000 \mathrm{ft}$ & -70 to $190^{\circ} \mathrm{C}$ & $\begin{array}{l}\text { Electrical Resistive, } \\
\text { Refrigeration }\end{array}$ & $4 \mathrm{ft} \times 4 \mathrm{ft} \times 4 \mathrm{ft}$ \\
\hline
\end{tabular}

The Environmental Test Facilities have recently been used for External Tank Development Flight Instrumentation Relay Assembly Thermal Cycle Qualification and Acceptance Tests; International Space Station Control Moment Gyro Flight Support Equipment Adjustable Shims Thermal Vacuum Tests; and Reinforced Carbon-Carbon Crack Repair Deliquification tests.

The Hydrogen Cold Flow Facility is a low-pressure, high-flow-rate closed loop cold flow test facility with two 225,000 gallon hydrogen storage tanks. It is a multi-purpose facility for low pressure system tests of hydrogen engine and subsystem components. Liquid hydrogen can flow from one 225,000-gallon storage tank through the test article into a second 225,000-gallon storage tank at a rate of 1,800 gallons per minute. The rate can be increased to 
5,000 gallons per minute as needed. The facility also can run tests using gaseous nitrogen, helium, and missile grade air. The facility can accommodate test articles up to $20-\mathrm{ft}$ by 20 -ft by $15-\mathrm{ft}$ under roof or even larger sizes on the adjoining apron. The Hydrogen Cold Flow Facility has most recently been used by the Space Shuttle Main Engine Liquid Air Insulation tests as part of the Return to Flight of the Space Shuttle.

\begin{tabular}{|l|l|}
\hline \multicolumn{2}{|c|}{ Table 11. Hydrogen Cold Flow Facility Capabilities } \\
\hline $\mathrm{LH}_{2}$ & 450,000 gallons at 50 psig \\
\hline $\mathrm{LH}_{2}$ flow & Up to 5,000 gallons per minute \\
\hline $\mathrm{GH}_{2}$ & 1 -inch line, at 3,100 psig \\
\hline $\mathrm{GHe}$ & 1 -inch line, at 4,200 psig \\
\hline $\mathrm{GN}_{2}$ & 1 -inch line, $1,500 \mathrm{psig}$ \\
\hline Missile-Grade Air & 1 -inch line, 500 psig \\
\hline Industrial water & 80 psig \\
\hline Hydraulics & $20 \mathrm{gpm}$ at 3,000 psig \\
\hline Low speed digital data & 200 sps \\
\hline High speed digital data & 250,000 sps \\
\hline Real-time video with sound & 30 frames per second \\
\hline High speed film camera & 400 frames per second \\
\hline High speed digital video & 1,000 frames per second for 52 seconds \\
\hline
\end{tabular}

The Optical Propagation Tunnel Facility is a 330 -meter still-air line-of-sight tunnel for testing optical systems, sensors and components. It is 4 -ft wide and can be bridged by a customer-supplied trolley. It provides an enclosed, still-air, controlled access space for guidance, navigation, and control simulations and tests of automated rendezvous and docking systems with flight-like degrees of freedom. The Optical Propagation Tunnel Facility has been used by both the Advanced Video Guidance Sensor Tests and the Demonstrator for Autonomous Rendezvous Technology.

Test Facility 300 has three vacuum chamber facilities used to conduct hazardous tests using cryogens and heat loads. Active test positions at Test Facility 300 include a 12 foot horizontal chamber, a 15 foot vertical chamber and a 20 foot vertical chamber. The dome section of each vacuum chamber is removable to allow installation of large test articles. Each vacuum chamber can be operated separately allowing independent test projects to be run simultaneously.

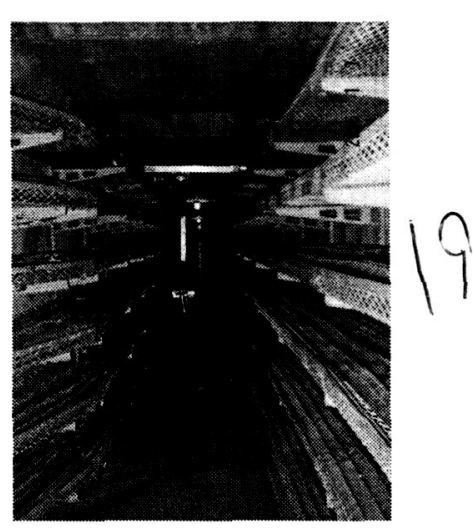

\begin{tabular}{|l|l|l|l|}
\hline \multicolumn{4}{|c|}{ Table 12. Test Facility $\mathbf{3 0 0}$ Vacuum Chambers } \\
\hline & $\mathbf{1 2} \mathrm{ft}$ vacuum chamber & $\mathbf{1 5} \mathrm{ft}$ vacuum chamber & $\mathbf{2 0} \mathrm{ft}$ vacuum chamber \\
\hline Dimensions & $\begin{array}{l}12 \mathrm{ft} \text { diameter by } 15 \mathrm{ft} \\
\text { long carbon steel chamber }\end{array}$ & $\begin{array}{l}15 \mathrm{ft} \text { diameter by } 25 \mathrm{ft} \text { tall } \\
\text { stainless steel chamber }\end{array}$ & $\begin{array}{l}20 \mathrm{ft} \text { diameter by } 35 \mathrm{ft} \text { tall } \\
\text { stainless steel chamber }\end{array}$ \\
\hline Vacuum level & $10^{-3}$ torr & $10^{-3}$ torr (future $10^{-6}$ torr) & $10^{-8}$ torr \\
\hline Radiant heat load & $20 \mathrm{BTU} / \mathrm{ft}^{2}-\mathrm{s}$ & None & none \\
\hline Rapid pump-down & High pressure $\mathrm{GN}_{2}$ ejector & None & High pressure $\mathrm{GN}_{2}$ ejector \\
\hline Residual Gas Analyzer & None & None & Yes \\
\hline
\end{tabular}

\begin{tabular}{|l|l|}
\hline \multicolumn{2}{|c|}{ Table 13. Test Facility 300 Facility Capabilities } \\
\hline $\mathrm{LH}_{2}$ & $\begin{array}{l}\text { Offload to test articles from government- } \\
\text { owned tankers, capacity } 12,000 \text { gallons }\end{array}$ \\
\hline $\mathrm{GH}_{2}$ & 3-inch line, at 4,200 psig \\
\hline $\mathrm{GHe}$ & 1.5 -inch line, at 4,200 psig \\
\hline $\mathrm{GN}_{2}$ & 3-inch line, $4,200 \mathrm{psig}$ \\
\hline $\mathrm{LN}_{2}$ storage & 13,500 gallons at $50 \mathrm{psig}$ \\
\hline Missile-Grade Air & 1.5 -inch line, 3,500 psig \\
\hline Industrial water & $150 \mathrm{psig}$ \\
\hline Hydraulics & 10 gpm at 3,000 psig \\
\hline
\end{tabular}

11

American Institute of Aeronautics and Astronautics 


\begin{tabular}{|l|l|}
\hline Low speed digital data & 200 sps \\
\hline High speed digital data & 250,000 sps \\
\hline Real-time video with sound & 30 frames per second \\
\hline High speed film camera & 400 frames per second \\
\hline High speed digital video & 1,000 frames per second for 52 seconds \\
\hline
\end{tabular}

Test Facility 300 has most recently been used for External Tank Foam testing in support of the Return to Flight of the Space Shuttle. The 12-ft vacuum chamber was used to simulate the ascent pressure and temperature profiles seen on the External Tank. Concurrent with the External Tank panel testing, the 20 - $\mathrm{ft}$ vacuum chamber was used for zero boil-off tests with the Multipurpose Hydrogen Test Bed as part of an MSFC inhouse cryogenic management program.

\section{Wind Tunnel Facilities}

The Aerodynamic Research Facility is an intermittent tri-sonic blow down tunnel, operating from pressure storage to vacuum or atmospheric exhaust. The test section measures 14-inch by 14-inch with interchangeable sections. The transonic section provides for Mach numbers of 0.2-1.3, 1.46, and 1.96. The supersonic section provides

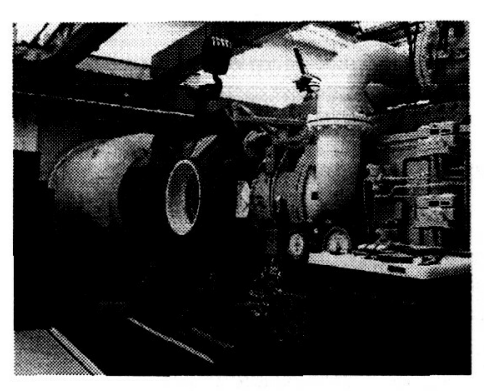
for Mach 2.74 - 4.96. The test section size ( $\mathrm{H} \mathrm{x} \mathrm{W} \mathrm{x}$ L) is 14-inch $x$ 14-inch $x$ 24-inch.
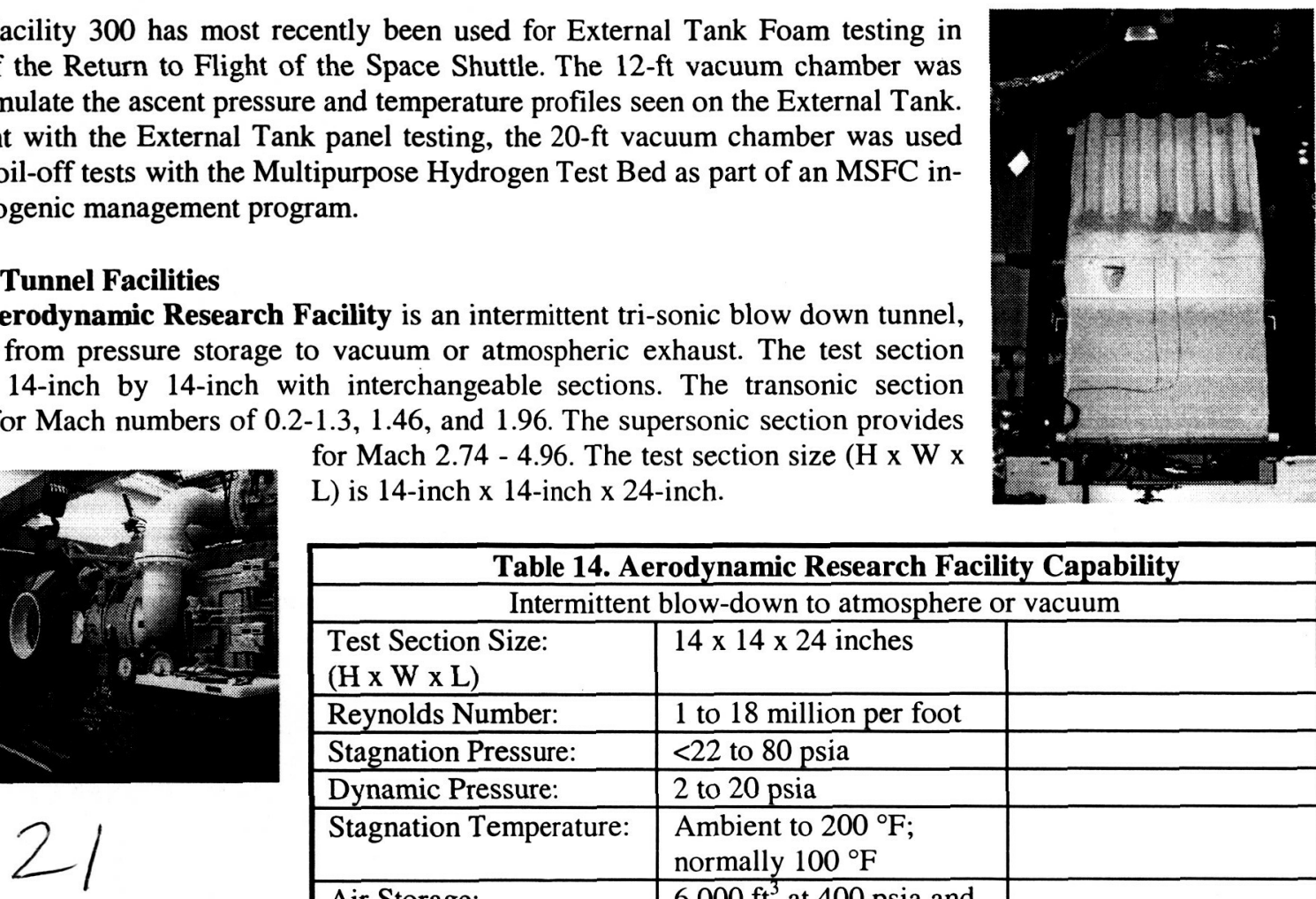

\begin{tabular}{|c|c|c|}
\hline \multirow{2}{*}{\multicolumn{3}{|c|}{$\begin{array}{l}\text { Table 14. Aerodynamic Research Facility Capab } \\
\text { Intermittent blow-down to atmosphere or vacuum }\end{array}$}} \\
\hline & & \\
\hline $\begin{array}{l}\text { Test Section Size: } \\
(\mathrm{H} \times \mathrm{W} \times \mathrm{L})\end{array}$ & $14 \times 14 \times 24$ inches & \\
\hline Reynolds Number: & 1 to 18 million per foot & \\
\hline Stagnation Pressure: & $<22$ to 80 psia & \\
\hline Dynamic Pressure: & 2 to $20 \mathrm{psia}$ & \\
\hline Stagnation Temperature: & $\begin{array}{l}\text { Ambient to } 200^{\circ} \mathrm{F} ; \\
\text { normally } 100^{\circ} \mathrm{F}\end{array}$ & \\
\hline Air Storage: & $\begin{array}{l}6,000 \mathrm{ft}^{3} \text { at } 400 \text { psia and } \\
100{ }^{\circ} \mathrm{F}\end{array}$ & \\
\hline Vacuum Storage: & $42,000 \mathrm{ft}^{3}$ at $0.1 \mathrm{psia}$ & \\
\hline Run Rate: & $\begin{array}{l}15 \text { to } 20 \text { runs per } 8 \text {-hour } \\
\text { shift }\end{array}$ & \\
\hline Angle of Attack: & $\begin{array}{l}-10 \text { to }+10 \text { degrees }(90 \\
\text { degrees with offset sting) }\end{array}$ & \\
\hline \multicolumn{3}{|c|}{ Interchangeable test sections } \\
\hline Test section & Transonic & Supersonic \\
\hline Nozzle & 3-Fixed contour blocks & $\begin{array}{l}\text { Variable contour } \\
\text { plates }\end{array}$ \\
\hline Mach Range & $0.2-1.3,1.46,1.96$ & $2.74-4.96$ \\
\hline Run Time & 60 to 90 seconds & 30 to 40 seconds \\
\hline Recharge Time & 10 to 15 minutes & 15 to 20 minutes \\
\hline Data Acquisition & \multicolumn{2}{|c|}{$\begin{array}{l}200 \text { channel pressure scanning system; forces and } \\
\text { moments measured by an internal, } 6 \text { component, } \\
\text { strain gage balance }\end{array}$} \\
\hline Flow Visualization & \multicolumn{2}{|c|}{$\begin{array}{l}\text { Schlieren, Shadowgraphs, Oil Flows, and High } \\
\text { speed video }\end{array}$} \\
\hline
\end{tabular}




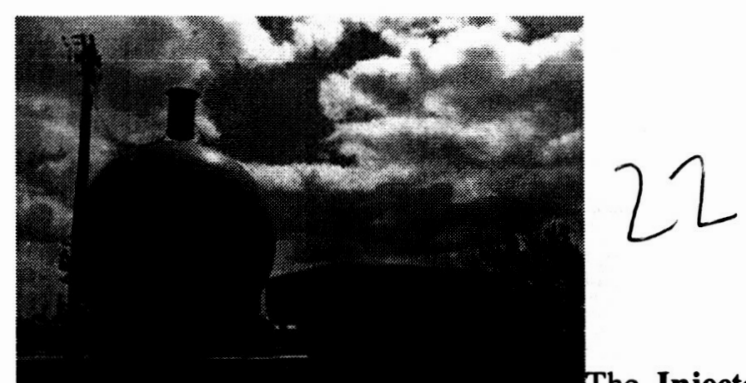

The Injector Test Rig is a pressure flow facility used to evaluate performance of injectors. Two flow systems deliver simulated, non-reactive propellants (water representing LOX and silicon oil representing fuel). Flow delivery is via pressurized supply vessels and throttled by flow control valves. There is off-line de-aeration capability along with injectant filtration to 20 microns. Determination of spray mass distribution and mixture ratio is possible using a patternator to capture and measure injector discharge. An optical system is used to accurately measure propellant distribution. Injectant pressures to 275 psig and flow rates to $15 \mathrm{gpm}$ on each delivery system are possible. Instrumentation consists of a flow system and model pressures, flow rates, and propellant simulant temperature. Spray mass distribution is measured across a 4-ft by 4-ft collection grid into 625 discrete collection tubes.

The Calibration Wind Tunnel Facility is an open-jet type, 6-inch x 6-inch inlet test section with a maximum flow velocity of $350 \mathrm{ft} / \mathrm{s}$. The facility is used to calibrate three- and five-hole flow direction probes using an automated calibration process that positions the probe over \pm 30 degrees in the pitch and yaw planes, sets the velocity in the test section, and prints out the data in summary form for the user.

The Solid Rocket Motor Airflow Facility is a high pressure blow-down system with 1,900 psia storage vessel supply and atmospheric discharge after passing through a Solid Rocket Motor test article. The facility provides the full-scale Mach number and Reynolds number for 10-percent scale advanced Solid Rocket Motor models. The facility can provide bore flow or mass injection through porous walls and investigate affects of gimbaling submerged nozzles, slot/port interactions, and other flow disturbances on internal flow. The facility provides an inlet pressure range of 600 to 1200 psia and a mass flow range of 20 to $320 \mathrm{lb} / \mathrm{s}$. Test durations can run from 30 to 300 seconds. Instrumentation includes a sub-critical mass flow venturi meter, 150 channel electronic pressure scanning system, 240 channel low-level voltage input data system (temperatures, strains), and 28 analog tape high frequency channels (pressures, accelerometers, strains). Additionally, there is specialized instrumentation for Laser Doppler Velocimetry, pressure probes/rakes, and hot-wire measurements. evaluate the performance of nozzles with exit diameters up to ten inches. It features a heated core flow supply, variable test chamber pressure using a two-stage ejector system, and thrust and side force components measurements. Nozzle core flow is $8 \mathrm{lb} / \mathrm{s}$ @ 25 to 350 psia and up to $350{ }^{\circ} \mathrm{F}$. The test chamber pressure can range from atmospheric to 0.05 psia with run times of two to three minutes. Instrumentation consists of steady and unsteady pressure measurements, test cabin pressure and temperature, up to 50 model pressures, calibrated load cells to measure thrust and side forces, a calibrated venturi for nozzle mass flow, and nozzle exit flows visualized with Schlieren.

The Air Flow Turbine Test Equipment facility is a blow-down system from 420 psia supply to atmosphere or vacuum. It features a stainless steel tunnel with two $6,000 \mathrm{ft}^{3}$ storage tanks, closed-loop control of inlet $P_{o}$ and $T_{o}$, pressure ratio, and shaft speed. Inlet flow is conditioned with a wide-angle diffuser, a honeycomb flow straightener, screens, and sine law contraction. It also features a torque meter, gearbox, and $600 \mathrm{hp} \mathrm{DC}$ dynamometer for power measurement and 13

American Institute of Aeronautics and As

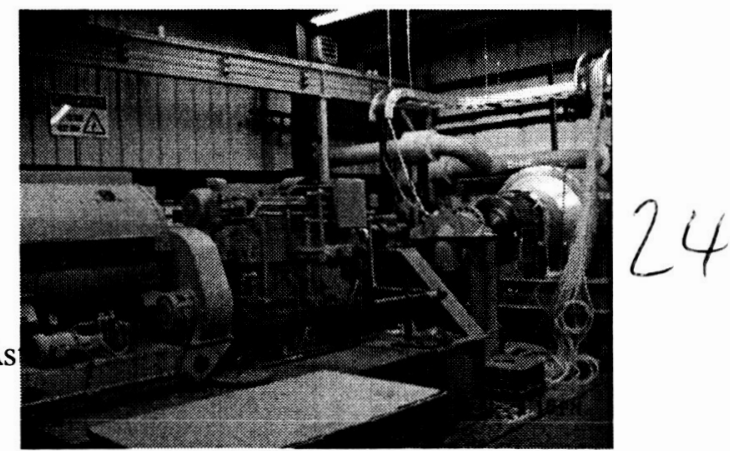


absorption. Air temperature control is provided by in-line stainless steel tube bundles heated by an off-line electric heater system. A 100-channel slip ring is used for on-rotor measurement.

\begin{tabular}{|l|l|}
\hline \multicolumn{2}{|c|}{ Table 15. Air Flow Turbine Test Equipment Facility Capability } \\
\hline \multicolumn{2}{|c|}{ Blow-down from 420 psia to atmosphere or vacuum } \\
\hline Shaft speed range & $+/-14,000 \mathrm{rpm}$ \\
\hline Inlet Pressure range & 30 to $300 \mathrm{psia}$ \\
\hline Exit Pressure range & Atmosphere to $0.05 \mathrm{psia}$ \\
\hline Inlet Temperature range & 530 to $830^{\circ} \mathrm{R}$ \\
\hline Torque range & $+/-1000 \mathrm{ft}-\mathrm{lb}$ \\
\hline $\begin{array}{l}\text { Power absorption/ motoring } \\
\text { capacity }\end{array}$ & $600 \mathrm{hp}(900$ transient) \\
\hline Inlet Flow Turbulence Intensity & Approximately $10 \%$ \\
\hline Test Duration & 100 seconds to 20 minutes \\
\hline
\end{tabular}

Instrumentation includes subsonic mass flow venturi meters and sonic critical flow meters; an in-line torque meter with $30 \mathrm{ft}-\mathrm{lb}, 500 \mathrm{ft}-\mathrm{lb}$, and $1000 \mathrm{ft}-\mathrm{lb}$ torque cartridges; a 512 channel electronic pressure scanning system; a 240-channel low-level-voltage-input data system (temperatures, strains), and a 6-channel remote control instrumentation positioning system. Additionally, there is specialized instrumentation for Laser Doppler Velocimetry, high-speed video/film, and hot-wire measurements, and a 100-contact slip ring system for on-rotor unsteady pressure measurements.

The Water Flow Inducer Test Loop Facility is a fluid-flow facility constructed of 6-inch and 8-inch diameter stainless steel pipe for conducting suction performance studies of turbopumps. It is a closed-loop, continuous water flow system (about 400 gallons total volume) driven by a 150 horsepower AC motor with 4:1 belt/pulley driveline with a variable speed controller for continuous adjustment of speed. The facility also features a stainless steel 100 gallon inline accumulator/de-aeration tank, a 50 horsepower stainless steel auxiliary centrifugal pump, an air pressurization/vacuum system for loop pressure control, and a heat exchanger for water temperature control.

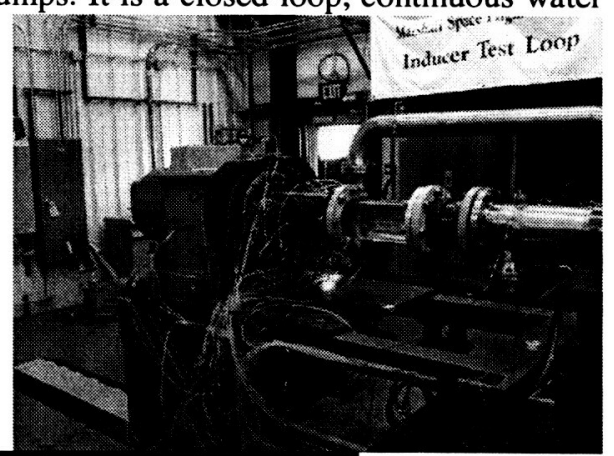

\begin{tabular}{|l|l|}
\hline \multicolumn{2}{|c|}{ Table 16. Water Flow Inducer Test Loop Facility Capability } \\
\hline Shaft speed range & 1,000 to $7,000 \mathrm{rpm}$ (either direction) \\
\hline Flow rate range & 250 to $3,000 \mathrm{gpm}$ \\
\hline Water Temperature range & 65 to $150^{\circ} \mathrm{F}$ \\
\hline Inlet Pressure range & 1 to $100 \mathrm{psia}$ \\
\hline Discharge Pressure range & Atmosphere to $200 \mathrm{psia}$ \\
\hline Power/Torque range & $100 \mathrm{hp} / 100 \mathrm{ft}-\mathrm{lb} \mathrm{max}$ \\
\hline $\begin{array}{l}\text { Power absorption/ motoring } \\
\text { capacity }\end{array}$ & $600 \mathrm{hp}(900$ transient) \\
\hline De-aeration & Down to 3 ppm \\
\hline
\end{tabular}

Instrumentation at the Water Flow Inducer Test Loop is a PC-based data acquisition system reading a 6-inch turbine type flow meter, 50 low frequency pressure transducers in the 1 to 65 psia range, 20 low frequency pressure transducers in 1 to 250 psia range, 28 analog tape high frequency channels (pressures, accelerometers, strains), a 100-contact high-speed slip ring system with shaft encoder, specialized instrumentation. (Laser Doppler Velocimetry, high-speed video/film, hot-wire), and a rotating balance to measure 3-forces and 3-moments during operation.

The Pump Test Equipment Facility features a closed loop water system with 10,000 gallon reservoir, electrical coil heating in the reservoir, dissolved oxygen monitoring, all-stainless piping with a 12-inch diameter inlet, a flow meter and flow

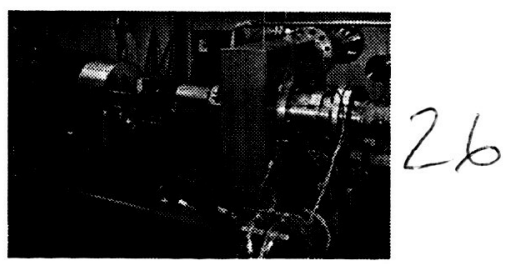


control quiet valve, and a torque meter and 350 horsepower drive motor. Instrumentation includes a steady state data system for test article and facility pressure monitoring. Unsteady data is measured in real time and recorded with 1 $\mathrm{Hz}$ to $30 \mathrm{kHz}$ bandwidths.

\begin{tabular}{|l|l|}
\hline \multicolumn{2}{|c|}{ Table 17. Pump Test Equipment Facility Capability } \\
\hline Shaft speed range & 360 to $3,600 \mathrm{rpm}$ \\
\hline Flow rate range & 300 to $3,000 \mathrm{gpm}$ \\
\hline Inlet Total Pressure range & $4-75 \mathrm{psia}$ \\
\hline Pump Pressure rise & 0 to $350 \mathrm{psid}$ \\
\hline Shaft torque range & $0-500 \mathrm{ft}-1 \mathrm{bf}$ \\
\hline Drive line power & $0-350 \mathrm{hp}$ \\
\hline Water Temperature & $60^{\circ} \mathrm{F}-160^{\circ} \mathrm{F}$ \\
\hline
\end{tabular}

The Water Flow Facility is an open loop, continuous water flow system with all stainless steel construction that accommodates model inlets up to 12 inches in diameter. It features $150 \mathrm{hp}, 3000 \mathrm{gpm}$ and $50 \mathrm{hp}, 1500 \mathrm{gpm}$ variable speed supply pumps and a 6000 gallon stainless steel supply tank and a $100 \mathrm{hp}, 3000$ gpm variable speed return pump with a stainless steel, 2,000 gallon discharge dump tank. Water temperature is controlled by a $30 \mathrm{~kW}$ water heater. Instrumentation includes 6-inch and 8-inch turbine type flow meters, 150 pressure measurement channels, 28 analog tape high frequency channels (pressures, accelerometers, strains), and specialized instrumentation (Laser Doppler Velocimetry, high-speed video/film, hot-wire).

\begin{tabular}{|l|l|}
\hline \multicolumn{2}{|c|}{ Table 18. Water Flow Facility Capability } \\
\hline Flow rate range & 50 to $3,000 \mathrm{gpm}$ \\
\hline Inlet Pressure max & $80 \mathrm{psia}$ \\
\hline Discharge Pressure max & $100 \mathrm{psia}$ \\
\hline Water Temperature & $70^{\circ} \mathrm{F}-100^{\circ} \mathrm{F}$ \\
\hline
\end{tabular}

The MSFC Materials Environment Test Complex (METCO) encompasses several test facilities including a Mach 4 combustion-driven wind tunnel (the Hot Gas Facility), a half million pound uniaxial tension test station, a thermal acoustic test station capable of delivering 172 decibels (low and high frequency ranges), a 1.5 million pound biaxial test facility which can be coupled with multiple environments, an arc-heater facility, and multiple radiant heating systems.

The HGF is a $\mathrm{GH}_{2} /$ air combustion-driven wind tunnel used primarily for thermal protection system testing and aero-thermal environments definition. During a test, combustion products are expanded from the combustion chamber through a two dimensional nozzle into a 16 in x 16 in x 40 in long test section. A Mach 4 flow environment is induced and convective heating from 3.5 to $25 \mathrm{BTU} / \mathrm{ft}^{2}-\mathrm{s}$ at total temperatures from $1,500^{\circ} \mathrm{F}$ to $3,000{ }^{\circ} \mathrm{F}$ can be obtained. The tunnel includes a $300 \mathrm{~kW}$ radiant heat system, a model insertion system with varying wedge angles, and test section shutter doors to protect the test article from start up and shut down shocks. The radiant heat system provides from 0 to $35 \mathrm{BTU} / \mathrm{ft}^{2}-\mathrm{s}$ concurrently with the Mach 4 test facility ideally suited for base only heating with programmable heating environments can be parameters of the facility to profile. If requested, oxygen may maintain $21 \%$ oxygen. Test generated to follow a test article also offers thermal imaging real time thermal response and of test articles can be recorded and 16-mm movie can record up to 72 channels of instrumentation article; more channels are shop capabilities are also

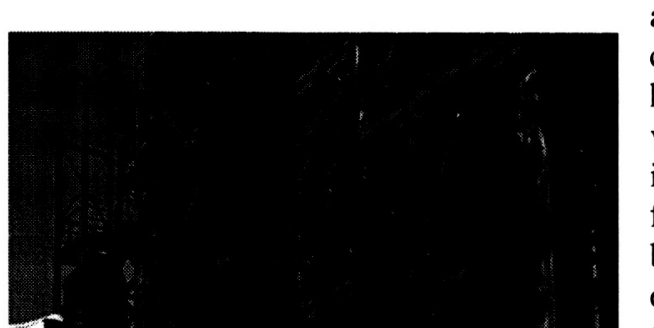

and can be combined convective heat inputs to make a heating environments. Radiantvacuum is also available. All individually profiled within the follow a prescribed flight heating be added to the combustor flow to environments can also be temperature profile. The $\mathrm{HGF}$ support to provide customers with gradients of the test article. Video from 30 to 500 frames per second to 10,000 frames per second. Up can be dedicated to each test available upon request. Machine available on site. The Hot Gas 
Facility is presently being used for Space Shuttle External Tank Foam Return to Flight testing.

The Tensile Test Station offers uniaxial load testing for test articles up to 19-inch $\mathrm{x} 48$-inch. The station load line is currently capable of tension loads up to $500,000 \mathrm{lbf}$ but the frame is capable of up to $1,000,000 \mathrm{lbf}$. Test articles can be thermally conditioned from $-423{ }^{\circ} \mathrm{F}$ using liquid helium to $+500{ }^{\circ} \mathrm{F}$ using gas heaters. Radiant heat and acoustic environments can be added upon request.

The Thermal Acoustic facility was developed in 1997 for the X-33 metallic Thermal Protection System (TPS) and is capable of duplicating the key acoustic loading and surface temperatures environments representative of the X-33 hypersonic flight. The facility was later modified in 1998 to double the acoustic energy in order test the Space Shuttle External Tank (ET) TPS materials. At present, this facility can deliver radiant heat from 0 to $30 \mathrm{BTU} / \mathrm{ft}^{2}$-s and up to 172 decibels onto a test article up to six feet square. The test article currently used for ET TPS testing has a fully characterized dynamic response which closely matches predicted flight responses. Test articles can be thermally conditioned from $-423^{\circ} \mathrm{F}$ using liquid helium to $+500^{\circ} \mathrm{F}$ using gas heaters upon request.

The Combined Environments Biaxial Loads facility is able to induce tension or compression loads of up to 1.5 million pounds in each axis onto a flat or curved test article up to 10 feet square or tanks up to 10 feet in diameter and up to 12 feet high dome-to-dome. The External Tank program has designed a flat test article for this facility

approximately six feet square which results in a uniform

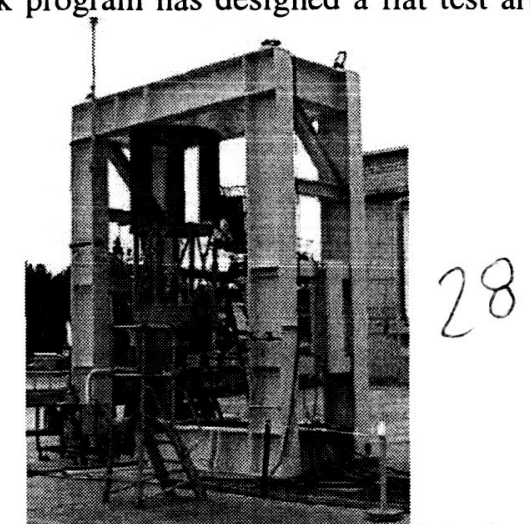

which duplicates a pressurized ET side wall or aft dome. The environments from the Thermal Acoustic Facility are then combined with this facility resulting in an ET TPS test facility capable of biaxial loads, acoustics, substrate dynamic response, radiant heat, and substrate cryogenic conditioning.

The Hyper-thermal Convective Test Facility will be used to test the thermal and ablative response of materials used to insulate the Shuttle Solid Rocket Motor nozzle. Gas compositions and temperature conditions which are representative of those encountered in the Reusable Solid Rocket Motor nozzle are simulated in this facility and used to develop and qualify new materials for flight. This facility will also be configured to support Magneto Hydrodynamic propulsion studies.

\section{Conclusion}

The Propulsion test facilities; Structural test facilities; Environmental test facilities; and Wind Tunnel facilities at Marshall Space Flight Center's Test Laboratory are a unique, highly flexible, adaptable, and capable national resource for ground testing of spacecraft and spacecraft systems.

\section{Acknowledgments}

Jeff Hamilton thanks Morayma McKinney and the staff of Total Solutions, Inc. for their invaluable assistance in preparing this paper, and Rebecca Farr, for showing the way. 
AIAA JPC Tucson paper

Marshall Space Flight Center Test Capabilities

Figure captions

Figure 1. Advanced Fuels Facility

Figure 2. 24-in Solid Rocket Motor at Solid Propulsion Test Facility

Figure 3. 48-in Solid Rocket Motor at Solid Propulsion Test Facility

Figures $2 \& 3$ both go with the "Solid Propulsion Test Facility" paragraph

Figure 4. External Tank panel test in Test Cell 101

Figure 5. 11-in GOX Hybrid Solid Rocket Motor test in Test Cell 103

Figures $4 \& 5$ both go with the "Test Cells" paragraph

Figure 6. Life Cycle Thruster test at Test Facility 115

Figure 7. Test Facility 115

Figures $6 \& 7$ both go with the "Test Facility 115" paragraph

Figure 8. RS-88 LOX/Ethanol engine test at Test Facility 116

Figure 9. Reaction Control System Hot-fire test at Test Facility 500

Figure 10. Advanced Engine Test Facility

Figure 11. Hazardous Structural Strength Test Facility

Figure 12. Cryogenic Structural Test Facility

Figure 13. External Tank Panel in Gilmore Load Tester NEW PICTURE ADDED 5/6

Figure 14. Structural Dynamics Modal Test in Structural Test High Bay

Figure 15. Structural Dynamics Vibration Test

Figure 16. Structural Dynamics Vibroacoustic Test

Figure 17. Structural Dynamics Pyrotechnic Shock Test

Figure 18. Environmental Test Facility

Figure 19. Optical Propagation Tunnel Facility

Figure 19 goes with the Optical Propagation Tunnel Facility paragraph

Figure 20. External Tank panel test in 12 -ft chamber at Test Facility 300

Figure 20 goes with the "Test Facility 300 " paragraph

Figure 21. 14-in Trisonic Wind Tunnel at Aerodynamics Research Facility

Figure 22. Injector Test Rig Facility

Figure 23. Nozzle Test Facility

Figure 24. Air Flow Turbine Test Facility

Figure 25. Water Flow Inducer Test Loop Facility

Figure 26. Pump Test Facility

Figure 27. Hot Gas Facility at Materials Environment Test Complex

Figure 28. Combined Environments Biaxial Loads Facility 